\title{
Venous blood ammonium levels in control subjects and in patients with disorders of the liver
}

\author{
D. SINNIAH ${ }^{1}$, T. T. FULTON, AND H. MCCULlOUGH \\ From the Royal Victoria Hospital, Belfast, Northern Ireland
}

SYNOPSIS Venous blood ammonium levels were studied in 106 control subjects and $47 \%$ patients with varying degrees of liver disorder. The resting venous blood ammonium was normally distributed in both male and female control subjects and was not influenced by either $\frac{D^{\circ}}{}$ the sex or the fasting state of the subject. In general it was also uninfluenced by age except that $\overrightarrow{\vec{\theta}}$ the level was found to be a little lower in subjects over 60 years of age probably due to their state of greater muscular inactivity.

The mean resting ammonium level in controls was $80 \cdot 0 \mu \mathrm{g} / 100 \mathrm{ml} \pm 17 \cdot 17 \mu \mathrm{g} / 100 \mathrm{ml}$ and the range (mean $\pm 2 \mathrm{SD}$ ) $46-114 \mu \mathrm{g} / 100 \mathrm{ml}$. Raised levels were obtained in $16.7 \%$ of patients with subclinical liver disorder, $62.5 \%$ with moderate liver disorder, and $85.5 \%$ with severe liver disorder, indicating a relationship between the severity of liver disorder and the resting 0 venous blood ammonium level. As the majority of patients with severe liver disorder were $\overline{\bar{O}}$ known to have varices the raised ammonium levels are likely to have been related to the greater magnitude and incidence of portal systemic shunts in those with severe liver disease.

The estimation of blood ammonium, although still largely a research investigation, may give information of considerable clinical importance. The relationship of ammonium to hepatic coma remains an enigma but despite occasional failure to find a correlation few investigators would be prepared to conclude that none exists.

Hitherto, errors caused by rapid decomposition of shed blood and by artefacts in ammonium determination have often invalidated the clinical significance of blood ammonium estimations (Perea and Nelson, 1964). Controversy exists as to how much of the ammonium removed from the blood represents preformed ammonium and how much is the result of decomposition of shed blood before and during analysis (Conway, 1935; Bromberg, Robin, and Forkner, 1960; Zieve, 1966). There has been no consistent agreement on the normal range of blood ammonium nor attention paid to the influence of possible

'Present address: Department of Paediatrics, University of Malaya, Kuala Lumpur, Malaysia.

Received for publication 15 April 1970. modifying factors such as age, sex, and the fasting or resting state of the subject.

The direct colorimetric method of determining blood ammonium concentration described by응 McCullough (1967) is a modification of the technique of Okuda, Fujii, and Kawashima음 (1965) and provides a simple and reliable method of simultaneously estimating the ammonium. content of a number of blood samples thus saving $N$ technicians' time. Atmospheric contamination, important in the diffusion technique, is not ao problem and elaborate equipment is not required Furthermore, the results are readily reproducible with a coefficient of variation of $1 \%$.

Because of the obvious advantages offered by 0 this technique, the time seemed opportune (1) too establish values for blood ammonium in appar- $\stackrel{\mathbb{D}}{\circ}$ ently healthy subjects resident in the Belfast area of Northern Ireland, and (2) to study the relationship between the severity of hepatic disorders assessed by clinical and biochemical criteria ando the resting and fasting venous blood ammoniums concentration. 


\section{Material and Methods}

A total of 106 control subjects and 47 patients with hepatic disorders took part in the present investigation. The control subjects were taken from various social classes and included doctors, nurses, medical students, laboratory personnel, secretarial staff, members of the armed forces, domestic servants, and labourers, none of whom was known to be suffering from hepatic, cardiac, or pulmonary diseases liable to influence the blood ammonium levels (Bessman and Evans, 1955; Dutton, Nicholas, Fisher, and Renzetti, 1959).

It has been shown that muscular activity can cause considerable increases in venous blood ammonium concentration (Allen and Conn, 1960; Sinniah, Fulton, and McCullough, 1970) and this effect can be largely counteracted by ensuring that the subjects rest for at least 30 minutes before the blood samples are withdrawn for analysis. For this reason both control subjects and patients with liver disorder were made to rest completely for a minimum period of $\mathbf{3 0}$ minutes before blood sampling.

Resting blood ammonium levels were obtained in $\mathbf{4 6}$ male and $\mathbf{4 0}$ female control subjects while the remaining 13 male and seven female subjects had also fasted for 12 hours. The control subjects were allocated into groups according to sex, age (20-39, 40-59, 60-79 years), and their state of satiety.

The 47 patients with liver disorders included 33 with cirrhosis, nine with chronic hepatitis, four recovering from acute hepatitis, and one with healed hepatic abscess. They were carefully examined and allocated into three groups according to their hepatic status.

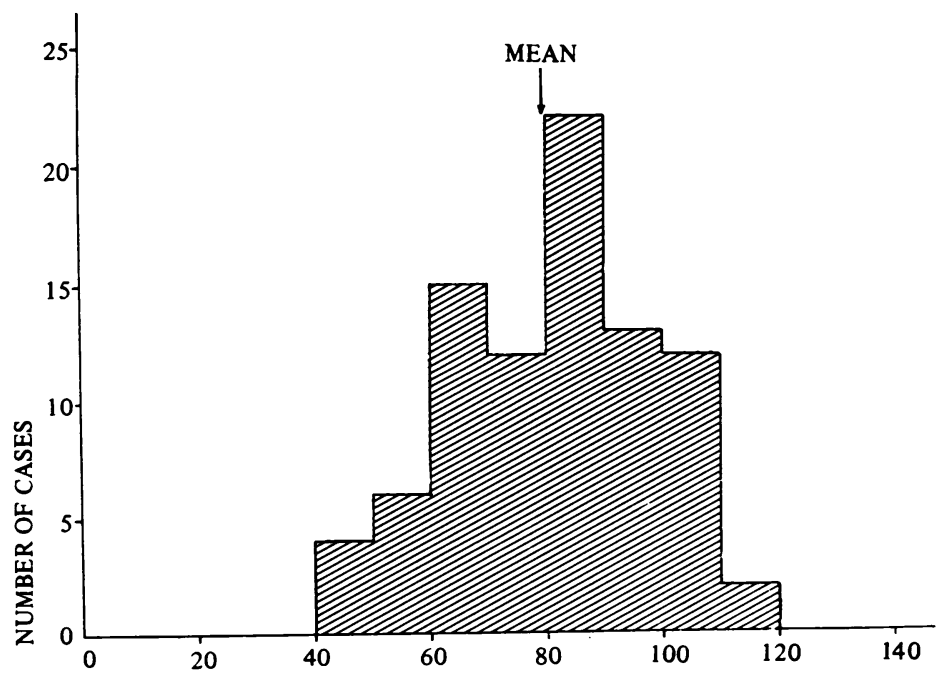

Blood Ammonium in $\mu \mathrm{G} / 100 \mathrm{ML}$

Fig. 1 Frequency distribution of resting venous blood ammonium in normal subjects.
GROUP 1: SUBCLINICAL LIVER DISORDER Patients with no demonstrable clinical signs of liver disease and in whom the diagnosis depended $\stackrel{0}{5}$ upon the past history and biochemical abnor- 은 mality. There were 12 patients in this group, two with cirrhosis, five with chronic hepatitis, four recovering from acute hepatitis, and one with healed hepatic abscess. The mean age of these patients was 33.8 years and the range $19-60$ years.

GROUP 2: MODERATE LIVER DISORDER Patients with both clinical signs and biochemical abnormalities of liver disease, but who had neither the clinical manifestations nor any previous history of hepatic encephalopathy. There were 16 patients in this group, 12 with cirrhosis and four with chronic hepatitis. Their mean age $\infty$ was $50 \cdot 8$ years and the range $30-67$ years.

\section{GROUP 3: SEVERE LIVER DISORDER}

Patients with clinical and biochemical indications of liver disease who had either been in pre-coma or coma immediately before the period of investi- ב gation, subsequently developed such a disorder $\stackrel{\mathbb{Q}}{-}$ or showed persistent signs of hepatic encephalopathy. This group comprised 19 cirrhotic patients whose ages ranged from 32 to 72 years, with a mean of 56.3 years. That patients in group 3 were generally older than those less severely affected is probably an indication that in them the disease was of longer standing and greater progression.

Using the direct colorimetric method described by McCullough (1967) venous blood ammonium levels were determined in all cases with the subjects resting after a 12-hour fast. The results are expressed in micrograms of ammonium nitrogen/ $100 \mathrm{ml}$ blood.

\section{Results}

The mean resting, non-fasting venous blood $\frac{T}{O}$ ammonium level in 86 control subjects was 80 $\mu \mathrm{g} / 100 \mathrm{ml}(\mathrm{SD} 17 \cdot 17 \mu \mathrm{g} / 100 \mathrm{ml}$ ) and $95 \%$ of the $\sigma$ ammonium levels ranged between 46 and $114 \mathrm{~N}$ $\mu \mathrm{g} / 100 \mathrm{ml}$. There was no appreciable difference in $\underset{\mathrm{N}}{\mathrm{N}}$ the ammonium levels between male and female ${ }_{0}$ subjects (mean values of 80.26 and $79.68 \mu \mathrm{g} / \stackrel{<}{\circ}$

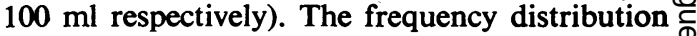
of the resting blood ammonium level in the $86 \stackrel{\infty}{\sim}$ male and female controls is shown in Figure 1.

FREQUENCY DISTRIBUTION OF VENOUS BLOOD AMMONIUM WITH REGARD TO SEX

In males in the 46 resting male controls is shown in Figureco 
2. The histogram does not appear to show any marked skewness. A statistical analysis was done to determine if there was a normal distribution of venous blood ammonium in the male subjects. The results for skewness and kurtosis with infinite degrees of freedom were $0.2>P>0.1$ and $0.9>P>0.8$ respectively. These values are not significant at $\mathbf{P}=0.05$.

\section{In females}

The frequency distribution of blood ammonium in the 40 resting female controls is shown in Figure 3. The values for measuring skewness and kurtosis with infinite degrees of freedom were $0.5>\mathrm{P}>0.4$ and $0.4>\mathrm{P}>0.3$ respectively.

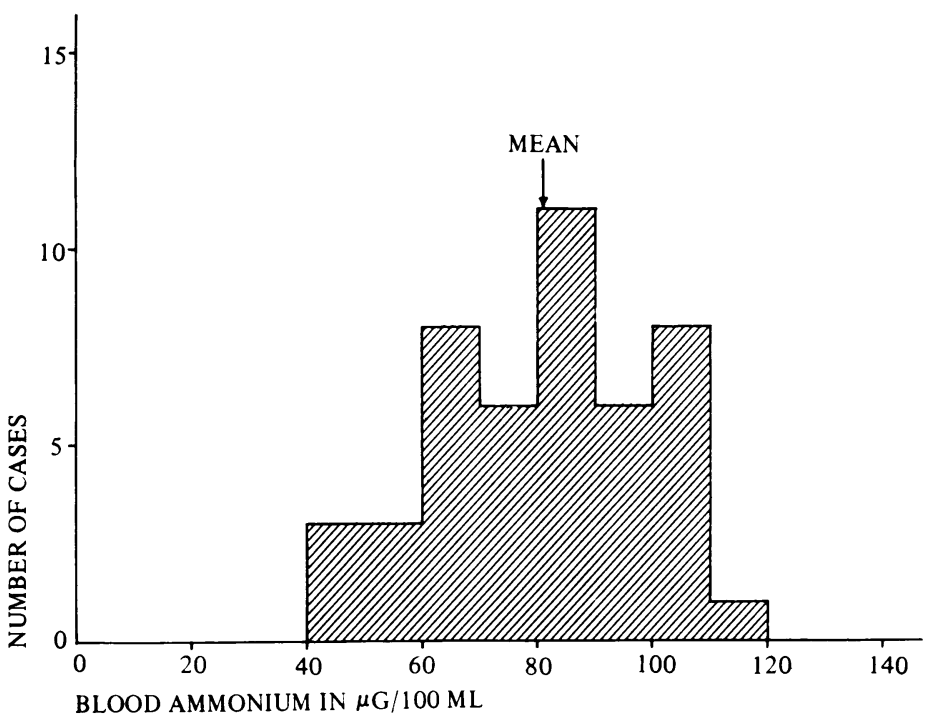

Fig. 2 Frequency distribution of resting venous blood ammonium in normal male subjects.

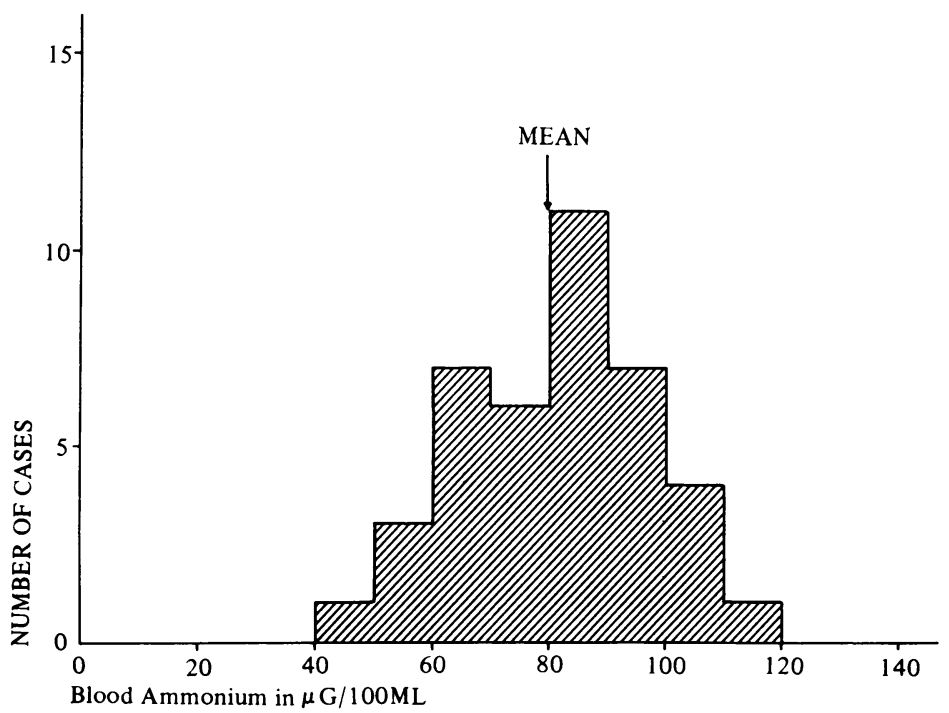

Fig. 3 Frequency distribution of resting venous blood ammonium in normal female subjects.
Neither of these values were significant at $\mathrm{P}=\frac{\varrho}{\overline{\bar{J}}}$ $0 \cdot 05$. There was therefore a normal distributiono of venous blood ammonium in the females as in the males.

THE INFLUENCE OF AGE ON THE RESTING BLOOD AMMONIUM LEVEL

In males

The relationship of venous blood ammonium tow age in the 46 resting male controls is shown in the $\overrightarrow{0}$ scattergram (Fig. 4). The mean ammonium value was $82.2 \mu \mathrm{g} / 100 \mathrm{ml}(\mathrm{SD} \pm 14.8 \mu \mathrm{g} / 100 \mathrm{ml}) \omega$ in controls aged 20-39 years, $86.7 \mu \mathrm{g} / 100 \mathrm{~m}$ ते $(\mathrm{SD} \pm 14.0 \mu \mathrm{g} / 100 \mathrm{ml})$ in controls aged $40-59 \%$ years, and $67.8 \mu \mathrm{g} / 100 \mathrm{ml}(\mathrm{SD} \pm 17.2 \mu \mathrm{g} / 100 \mathrm{ml}) \omega$ in controls aged 60-79 years (Table I).

It was found that there were no significant differences between the mean ammonium con-o centrations of the three groups of subjects:? variance ratio $F=3.2$ and at degrees of freedom $\mathrm{n}_{1}=2, \mathrm{n}_{2}=43, \mathrm{P}>0.05$.

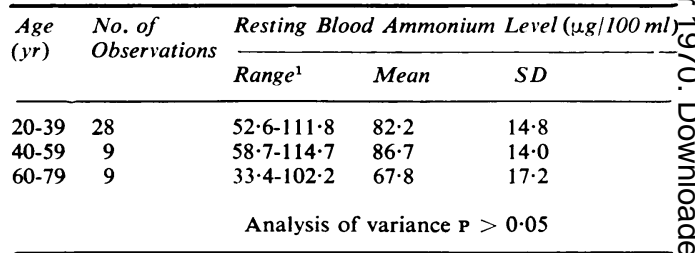

Table I Resting venous blood ammonium levels in males aged 20-39, 40-59, and 60-79 years

${ }^{1}$ Range $=$ mean $\pm 2 \mathrm{SD}$

In females

The relationship of the resting venous ammonium level to age in the 40 female controls is shown in the scattergram (Fig. 5). The mean ammonium level was $83.9 \mu \mathrm{g} / 100 \mathrm{ml}(\mathrm{SD} \pm 15.6 \mu \mathrm{g} / 100 \mathrm{ml})$ 을 in controls aged 20-39 years, $82.0 \mu \mathrm{g} / 100 \mathrm{ml}$ $(\mathrm{SD} \pm 16.7 \mu \mathrm{g} / 100 \mathrm{ml})$ in controls aged $40-59$ 을 years, and $70 \cdot 8 \mu \mathrm{g} / 100 \mathrm{ml}(\mathrm{SD} \pm 15 \cdot 4 \mu \mathrm{g} / 100 \mathrm{ml})$ in controls aged 60-79 years (Table II). An' analysis of variance revealed no significant differ- $N$ ences between the mean ammonium concen-N trations of the resting subjects belonging to the

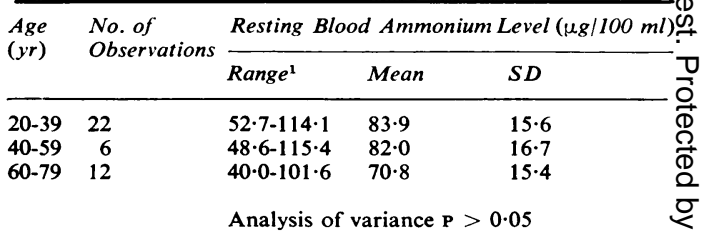

Table II Resting venous blood ammonium levels in females aged 20-39, 40-59, and 60-79 years

${ }^{1}$ Range $=$ mean $\pm 2 \mathrm{SD}$ 


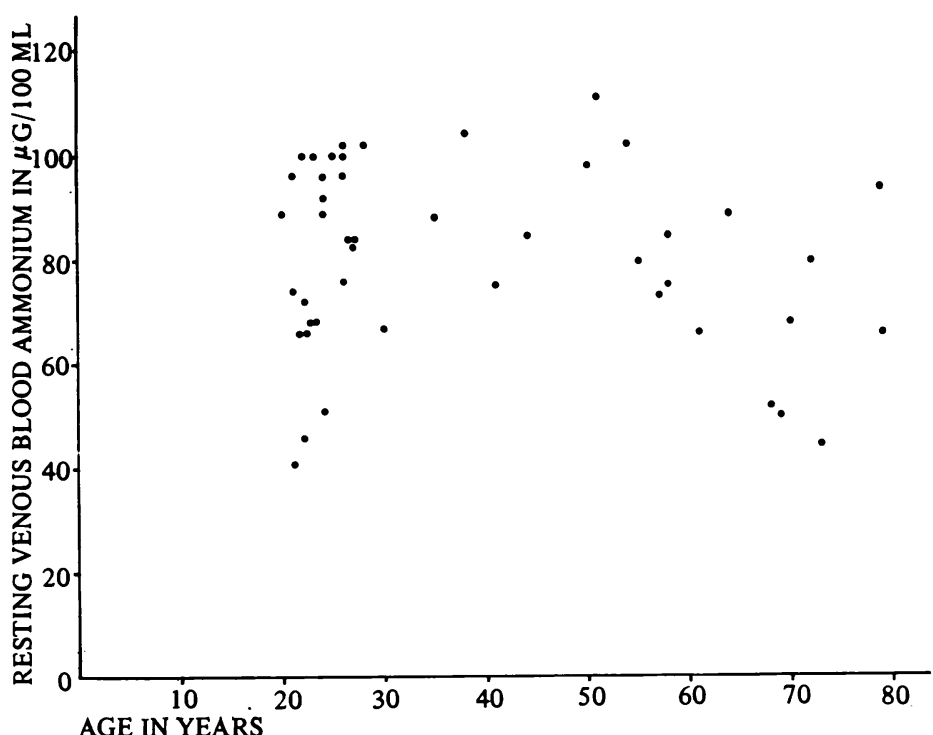

AGE IN YEARS

Fig. 4 Scattergram showing the relationship of resting venous blood ammonium to age in normal males.

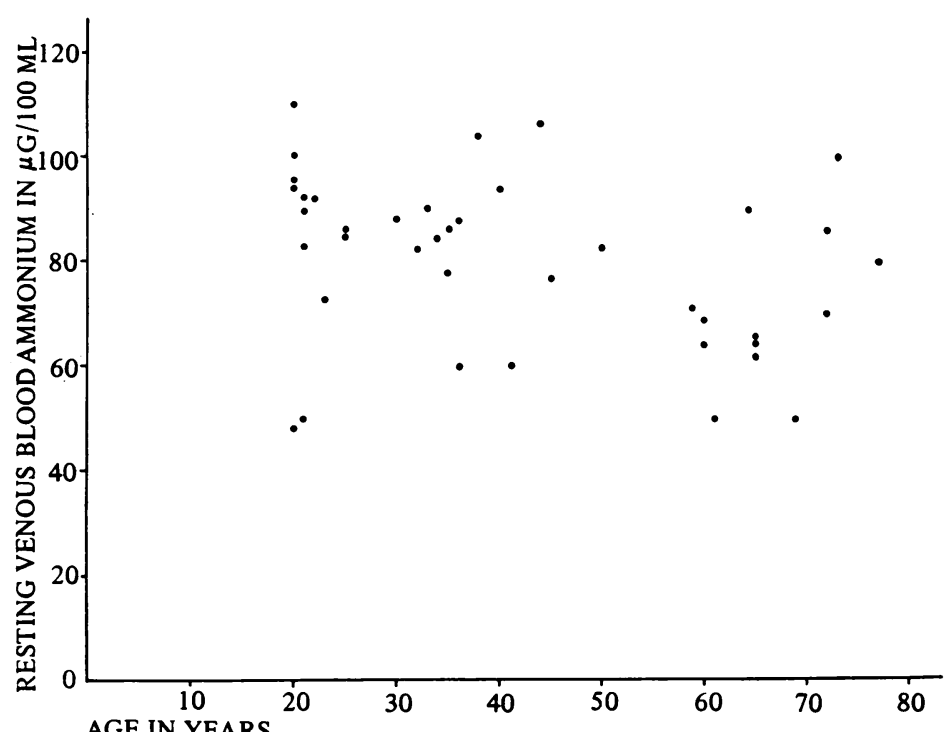

AGE IN YEARS

Fig. 5 Scattergram showing the relationship of resting venous blood ammonium to age in normal females.

\begin{tabular}{llllll}
\hline Group & $\begin{array}{l}\text { Standard Error } \\
\text { of Difference } \\
(\mu \mathrm{g} / 100 \mathrm{ml})\end{array}$ & $P=0.05$ & $\begin{array}{l}\text { Minimum } \\
\text { Significant } \\
\text { Difference } \\
(\mu \mathrm{g} / 100 \mathrm{ml})\end{array}$ & $\begin{array}{l}\text { Difference } \\
\text { in Means } \\
(\mu \mathrm{g} / 100 \mathrm{ml})\end{array}$ & $\begin{array}{l}\text { Probability at } \\
P=0.05\end{array}$ \\
\hline B-A & 4.816 & 2.00 & 9.632 & 1.84 & Not significant \\
B-C & 5.53 & 2.00 & 11.06 & 15.32 & $\begin{array}{l}\text { Significant } \\
\text { C-A }\end{array}$ \\
\hline 4.2536 & 2.00 & 8.5072 & -13.48 & Significant \\
\hline
\end{tabular}

Table IV Analysis to determine the significance of the difference in the means between the control groups

$A=$ controls aged 20-39 years

$B=$ controls aged $40-59$ years

$\mathrm{C}=$ controls aged $60-79$ years different age groups: variance ratio $F=2.79$ and $\frac{\varrho}{5}$ at degrees of freedom $n_{1}=2, n_{2}=37, P>0.05$, which is not significant.

When the resting venous blood ammonium levels of both male and female controls were $\Rightarrow$ grouped collectively according to age groups, it $\stackrel{\rho}{\stackrel{P}{~}}$ was found that there was no significant difference? between the mean blood ammonium level of the $\frac{\bar{y}}{\bar{m}}$ controls aged 20-39 years and those aged 40-59 $\frac{\mathrm{\rho}}{\vec{\gamma}}$ years. The mean blood ammonium level of the $\varrho$ controls aged 60 years and over was lower than that in the younger controls (Tables III and IV).

THE INFLUENCE OF SEX ON THE RESTING $\vec{\omega}$ VENOUS AMMONIUM LEVEL

$t$ Tests were undertaken to determine if there $\bar{O}$ were significant differences between the mean blood ammonium concentrations of male andio female controls belonging to the age groups $N$ $20-39,40-59$, and $60-79$ years. It was found that there were no significant differences between the $\mathrm{O}$ mean ammonium concentration of male andfemale controls. For the three groups $t=0.35$, $t=0.59$, and $t=0.42$, and at 48,13 , and $19{ }_{\Phi}$ degrees of freedom respectively, $0.8>P>0.7,3$ $0.6>\mathrm{P}>0.5$, and $0.7>\mathrm{P}>0.6$, which are not음 significant at $P=0.05$.

THE INFLUENCE OF FASTING ON THE RESTING VENOUS AMMONIUM LEVEL

The ammonium levels of 20 fasting controls subjects (13 male and seven female) aged 20-39ō years were compared with those of 50 non-气 fasting controls ( 28 male and 22 female) of thee same age group. The mean ammonium con- $\overrightarrow{\overrightarrow{0}}$ centrations in the fasting and non-fasting controls were $86.9 \mu \mathrm{g} / 100 \mathrm{ml}(\mathrm{SD} \pm 15.5 \mu \mathrm{g} /$ ? $100 \mathrm{ml}$ and range $55.9-117.9 \mu \mathrm{g} / 100 \mathrm{ml}$ ) and? $82.9 \mu \mathrm{g} / 100 \mathrm{ml}(\mathrm{SD} \pm 16.8 \mu \mathrm{g} / 100 \mathrm{ml}$ and range 49.3-116.5 $\mu \mathrm{g} / 100 \mathrm{ml}$ ) respectively. $t$ Tests: (Table V) show no significant difference between 3 the mean blood ammonium concentrations of fasting and non-fasting controls. It was also found 3 that there is no significant difference between the 'scatter' of the blood ammonium levels in the two groups of subjects, scatter $F=1 \cdot 17$ and ato $\mathrm{n}_{1}=49, \mathrm{n}_{2}=19$ degrees of freedom, $\mathrm{P}>0.05$, which is not significant.

\begin{tabular}{|c|c|c|c|c|}
\hline \multirow[t]{2}{*}{ Group } & \multirow{2}{*}{$\begin{array}{l}\text { No. of } \\
\text { Observations }\end{array}$} & \multicolumn{3}{|c|}{ Resting Blood Ammonium Level $(\mu \mathrm{g} / 100 \mathrm{~m} /)$} \\
\hline & & Mean & $S E$ & $S D$ \\
\hline $\begin{array}{l}\mathbf{A} \\
\mathbf{B} \\
\mathbf{C}\end{array}$ & $\begin{array}{l}50 \\
15 \\
21\end{array}$ & $\begin{array}{l}82 \cdot 96 \\
84 \cdot 80 \\
69 \cdot 48\end{array}$ & $\begin{array}{l}2 \cdot 31 \\
4 \cdot 22 \\
3 \cdot 57\end{array}$ & $\begin{array}{l}16 \cdot 80 \\
14 \cdot 74 \\
15 \cdot 90\end{array}$ \\
\hline
\end{tabular}

Table III Mean resting venous blood ammonium level in controls (86 males and females) aged 20-39, 40-59, and 60-79 years

$A=$ controls aged 20-39 years $B=$ controls aged 40-59 years

SE = standard error $C=$ controls aged $60-79$ years
SD $=$ standard deviation 
Neither satiety nor fasting influenced the resting venous blood ammonium concentration in the control subjects.

THE RELATIONSHIP BETWEEN THE SEVERITY OF LIVER DISORDER AND THE FASTING VENOUS BLOOD AMMONIUM LEVEL

Figure 6 is a scattergram of the fasting venous blood ammonium levels in control subjects, and in patients with mild, moderate, and severe liver disorders, and Table VI shows the mean values and their standard deviations. Control subjects were found to have a mean fasting venous blood ammonium level of $86.9 \mu \mathrm{g} / 100 \mathrm{ml}(\mathrm{SD} \pm 15 \cdot 5$ $\mu \mathrm{g} / 100 \mathrm{ml}$ ) while patients with mild or subclinical

\begin{tabular}{lllllll}
\hline $\begin{array}{l}\text { Mean Blood Ammonium } \\
(\mu \mathrm{g} / 100 \mathrm{ml})\end{array}$ & $\begin{array}{l}\text { Mean } \\
\text { Difference } \\
(\mu \mathrm{g} / 100 \mathrm{ml})\end{array}$ & $\begin{array}{l}\text { Standard Error } \\
\text { of Difference } \\
(\mu \mathrm{g} / 100 \mathrm{ml})\end{array}$ & $\begin{array}{l}\text { Degrees } \\
\text { of } \\
\text { Freedom }\end{array}$ & \\
$\begin{array}{l}\text { Resting } \\
\text { Non-fasting }\end{array}$ & $\begin{array}{l}\text { Resting } \\
\text { Fasting }\end{array}$ & & & & & \\
\hline $\begin{array}{l}82.9 \\
(50)^{1}\end{array}$ & $\begin{array}{l}86.9 \\
(20)^{1}\end{array}$ & 4.0 & 4.4 & $\mathrm{t}=0.91$ & 68 & $0.4>\mathrm{P}>0.3$ \\
\hline
\end{tabular}

Table V Use of $t$ test to determine any significant difference in venous blood ammonium levels of fasting resting and non-fasting resting subjects aged 20-39 years

${ }^{1}$ Number of subjects studied in the respective groups

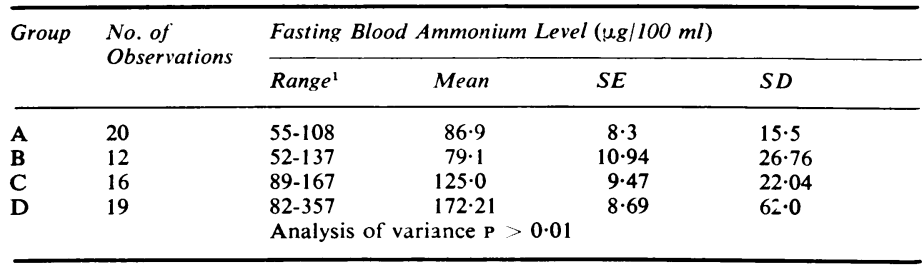

Table VI Fasting venous blood ammonium levels in subclinical, moderate, and severe liver disorder groups and in control group

${ }^{1}$ Range - from the lowest to the highest recorded value
Group A $=$ control
Group B = subclinical liver disorder
Group C $=$ moderate liver disorder
Group D = severe liver disorder

\begin{tabular}{|c|c|c|c|c|}
\hline Group & $\begin{array}{l}\text { SE of Difference } \\
(\mu \mathrm{g} / 100 \mathrm{ml})\end{array}$ & $P=0.05$ & $\begin{array}{l}M S D \\
(: \mu \mathrm{g} / 100 \mathrm{ml})\end{array}$ & $\begin{array}{l}\text { Difference in } \\
\text { Means } \\
(\mu \mathrm{g} / 100 \mathrm{ml})\end{array}$ \\
\hline B-A & $13 \cdot 0$ & $2 \cdot 0$ & $26 \cdot 0$ & $6 \cdot 9$ \\
\hline C-A & $12 \cdot 75$ & $2 \cdot 0$ & $25 \cdot 5$ & $40 \cdot 43^{1}$ \\
\hline D-A & 11.96 & $2 \cdot 0$ & 23.92 & $85 \cdot 31^{1}$ \\
\hline C-B & $13 \cdot 87$ & $2 \cdot 0$ & $27 \cdot 74$ & $47 \cdot 33^{1}$ \\
\hline D-B & $13 \cdot 15$ & $2 \cdot 0$ & $16 \cdot 3$ & $92 \cdot 21^{1}$ \\
\hline D-C & 12.90 & $2 \cdot 0$ & $25 \cdot 8$ & $44 \cdot 88^{1}$ \\
\hline
\end{tabular}

Table VII Analysis to show the significance of the difference in the means between the groups

'Significant at 0.05 probability

$\mathbf{A}=$ control

$\mathbf{B}=$ subclinical liver disorder

$\mathrm{C}=$ moderate liver disorder

$\mathrm{D}=$ severe liver disorder

MSD $=$ minimum significant difference liver disorder were found to have a mean ammo nium level of $79.1 \mu \mathrm{g} / 100 \mathrm{ml}(\mathrm{SD} \pm 27.76 \mu \mathrm{g}$ $100 \mathrm{ml}$ ). The mean ammonium level in patients with moderate liver disorder was $125.0 \mu \mathrm{g} / 100 \mathrm{~m}$. $(\mathrm{SD} \pm 22.04 \mu \mathrm{g} / 100 \mathrm{ml})$ while patients witl severe liver disorder had a mean ammoniunf? level of $172 \cdot 2 \mu \mathrm{g} / 100 \mathrm{ml}(\mathrm{SD} \pm 62.0 \mu \mathrm{g} / 100 \mathrm{ml})$ ?

Statistical analysis was used to determine $\mathrm{i}$ there were significant differences between the् mean venous blood ammonium levels in the foup groups of subjects. It was found that the variances ratio $F=21.84$ and at $n_{1}=3, n_{2}=63$ degrees of freedom, $P<0.01$ which is significant at $\mathbf{P}=0.05$. Calculation of the minimum signi $\vec{\omega}$ ficant difference between the means of the different groups showed that although there was no significant difference between the mean venous blood ammonium level of control subjects ando patients with subclinical liver disorder, there werêt (Tables VI and VII) highly significant differences

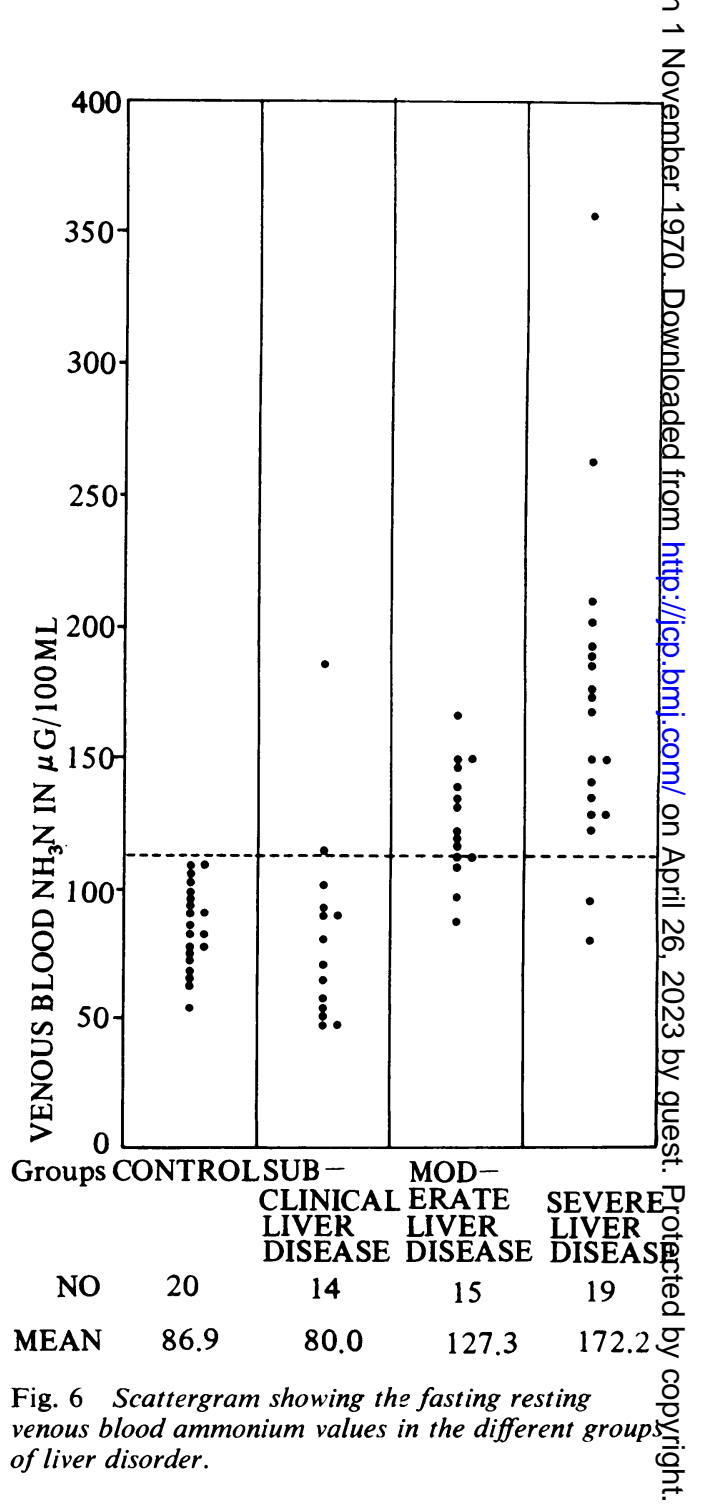


between the mean venous blood ammonium levels of (1) controls and patients with moderate liver disorder; (2) controls and patients with severe liver disorder; (3) patients with subclinical liver disorder and patients with moderate liver disorder; (4) patients with subclinical liver disorder and patients with severe liver disorder; and (5) patients with moderate liver disorder and patients with severe liver disorder.

All the 20 fasting controls had ammonium levels which fell within the range established earlier in 86 resting non-fasting male and female control subjects (normal range $46-114 \mu \mathrm{g} / 100 \mathrm{ml}$ ): $16.7 \%$ of patients with subclinical liver disorder, $62.5 \%$ of patients with moderate liver disorder, and $89.5 \%$ of patients with severe liver disorder had blood ammonium levels exceeding $114 \mu \mathrm{g} /$ $100 \mathrm{ml}$.

\section{Discussion}

The present study shows that the resting venous blood ammonium level is normally distributed in both male and female controls. Although there are no significant differences between the mean ammonium levels of subjects aged 20-39 and 40-59 years, the mean ammonium level of controls aged 60 years and over appears to be a little lower than that of younger subjects. This may be due to the state of greater muscular inactivity of the older subjects.

No significant differences were found between either the means or the scatter of the venous blood ammonium levels in fasting and non-fasting controls, indicating that in them no significant elevation of blood ammonium occurred in response to a normal meal containing protein. Nielsen, Liang, and Chey (1965) reported similar findings in their control subjects after a protein meal.

The normal resting venous blood ammonium level was found to be between 46 and $114 \mu \mathrm{g} /$ $100 \mathrm{ml}$, differing little from the range $48-113 \mu \mathrm{g} /$

\begin{tabular}{lc}
\hline Author & $\begin{array}{c}\text { Blood Ammonia } \\
\text { Nitrogen Range } \\
(\mu g / 100 ~ m l)\end{array}$ \\
\hline Barnett (1917) & $0-50$ \\
Stanojevic (1931) & $17-37$ \\
Conway (1935) & $0-38$ \\
Kirk (1936) & $18-40$ \\
McDermott and Adams (1954) & $50-79$ \\
Seligson and Hirahara (1957) & $75-196$ \\
Egense (1960) & $46-134$ \\
Burg and Mook (1963) & $10-70$ \\
Mondzac, Ehrlich, and Seegmiller (1965) & $17-80^{1}$ \\
Okuda et al (1965) & $100-150$ \\
McCullough (1967) & $48-113$ \\
Present study & $46-114$ \\
\hline
\end{tabular}

Table VIII Comparison of 'normal' venous blood ammonium results with values in other published reports

${ }^{1}$ Plasma nitrogen $\mu \mathrm{g} / 100 \mathrm{ml}$
$100 \mathrm{ml}$ reported by McCullough (1967). Previous workers using other methods of analysis had obtained very variable normal venous blood ammonium levels (Table VIII) making comparison of results impossible.

The present study shows a direct relationship between the severity of the liver disorder and the incidence and height of elevated blood ammonium levels, ie, $16.7 \%$ of those with subclinical liver disorder, $62.5 \%$ of patients with moderate liver disorder, and $89.5 \%$ of patients with severe liver disorder had raised venous blood ammonium levels. Phear, Sherlock, and Summerskill (1955) found normal blood ammonium levels in $10 \%$ of their patients with hepatic encephalopathy and this compares closely with our figure of $10.5 \%$. Phear et al (1955) discussed the confusion caused by the finding of a normal blood ammonium level in occasional cases of coma and of high ammonium levels in the absence of neuropsychiatric disturbance

The majority of patients in the 'severe liver disorder group' were known to have varices (though detailed investigation was not undertaken in every case) and this finding is in accord with and supports the present consensus of opinion that the blood ammonium level is a measure of portal-systemic shunting (Fenton, 1967). Furthermore, the $10.5 \%$ of patients in the 'severe liver disorder grcup' with normal blood ammonium levels may well have had severely impaired liver cell function rather than any significant portal-systemic shunting.

Susceptibility to hepatic coma has been thought to be directly related to the severity of impairment of liver function, the magnitude of the portalsystemic collateral circulation, and the amount of a toxic factor formed in the intestine. The greater the latter, the less severe need be hepatocellular dysfunction and the smaller the portal-systemic collateral circulation before cerebral manifestations appear (Zieve, 1966). Thus, the main cause of hepatic coma is not the same in all cases, and McDermott, Wareham, and Riddell (1955) distinguished between 'endogenous' and 'exogenous' varieties. The latter, with an almost invariably raised blood ammonium level, corresponds to the toxic intestinal cause, 'enterogenous coma', and often has a better prognosis than the spontaneous or 'endogenous' type with its basis in progressive parenchymal failure (Stahl, 1963). The blood ammonium level in this type of coma may be normal.

The blood ammonium level may not bear a strict relationship to encephalopathic symptoms at the time of sampling, and it has been suggested that it 'anticipates' the subsequent course of events, the maximum concentration being reached before coma is fully developed (Egense, 1960 and 1963). An increase in the blood ammonium level often precedes the onset of symptoms and a fall heralds recovery (Stahl, 1963; Fenton, 1965). Whereas sharp but transient rises in blood 
ammonium concentration may cause no untoward effects a sustained increase may be followed by the appearance of the clinical syndrome of hepatic encephalopathy.

We are grateful to Mr D. W. Neill, consultant biochemist, Royal Victoria Hospital, and to $\mathrm{Dr}$ J. D. Merrett, Department of Medical Statistics, The Queen's University of Belfast, for their help and advice. We thank Dr F. F. Kane, Mr G. W. Johnston, Professor H. W. Rodgers, and Dr J. A. Weaver for permitting us to study their patients. We are greatly indebted to our patients, medical and nursing colleagues, and other members of the hospital community, and to the many people of Belfast who willingly agreed to participate in this study.

This work was supported by a grant from the Research Committee of the Royal Victoria Hospital and represents part of a thesis submitted by one of us (D.S.) and accepted for the degree of Doctor of Medicine by Trinity College, University of Dublin.

\section{References}

Allen, S., and Conn, H. O. (1960). Observations on the effect of exercise on blood ammonia concentration in man. Yale J. Biol. Med., 33, 133-144.

Barnett, G. D. (1917). The micro-titration of ammonia, with some observations on normal human blood. J. Biol. Chem., 29, 459-462.

Bessman, A. N., and Evans, J. M. (1955). The blood ammonia in congestive heart failure. Amer. Heart $J$, 50, 715-719.

Bromberg, P. A., Robin, E. D., and Forkner, C. E., Jr. (1960). The existence of ammonia in blood in vivo with observations on the significance of the $\mathrm{NH}_{4}{ }^{+}-\mathrm{NH}_{3}$ system. J. clin. Invest., 39, 332-341.

Burg, P. V. D., and Mook, H. W. (1963). A simple and rapid method for the determination of ammonia in blood. Clin. chim. Acta, 8, 162-164.
Conway, E. J. (1935). Apparatus for the microdetermination $\frac{(\overline{6}}{4}$ certain volatile substances. IV. The blood ammonia, with observations on normal human blood. Biochem. J., 29) 2755-2772.

Dutton, R. Jr., Nicholas, W., Fisher, C. J., and Renzetti, A. D. Je (1959). Blood ammonia in chronic pulmonary emphysema." New Engl. J. Med., 261, 1369-1373.

Egense, J. (1960). Ammonium tolerance test. A diagnostic aid in

liver diseases. Acta med. Scand., 167, 53-59.
Egense, J. (1963). Ammonia and hepatic coma. Acta med. Scand $\frac{\square}{6}$ $173,7-17$.

Fenton, J. C. B. (1965). The factor relating plasma ammonia wit hepatic coma. J. clin. Path., 11, 126.

Fenton, J. C. B. (1967). The plasma ammonium and liver disease? Hosp. Med., 1, 491-493.

Kirk, E. (1936). The significance of the liver for the amino acid and ammonium metabolism. Acta Med. Scand., Suppl. $7 \vec{b}$ 1-17.

Mondzac, A., Ehrlich, G. E., and Seegmiller, J. E. (1965). A $\overrightarrow{\text { r }}$ enzymatic determination of ammonia in biological fluid w J. Lab. clin. Med., 66, 526-531.

McCullough, H. (1967). The determination of ammonia in whot blood by a direct colorimetric method. Clin. chim. Acta, 1 T⿰讠
297-304.

McDermott, W. V., Jr., and Adams, R. D. (1954). Episodion stupor associated with an Eck fistula in the human with particular reference to the metabolism of ammonia. J. clinf Invest., 33, 1-9.

McDermott, W. V., Jr., Wareham, J., and Riddell, A. G. (1955? Treatment of "hepatic coma" with L-glutamic acid. New Engl. J. Med., 253, 1093-1102.

Nielsen, O. F., Liang, Y. K., and Chey, W. Y. (1965). Effect of protein administration on ammonia levels of patients wite liver disease. Amer. J. Med. Sci., 250, 121-130.

Okuda, H., Fujii, S., and Kawashima, Y. (1965). A direct color metric determination of blood ammonia. Tokushima J. exp
Med., 12, 11-23.

Perea, V. D., and Nelson, R. S. (1964). Blood ammonia levels in primary and metastatic cancer of the liver. Clin. chim. Actô.

Phear, E. A., Sherlock, S., and Summerskill, W. H. J. (1955) Blood-ammonium levels in liver disease and "hepatio coma". Lancet, 1, 836-840.

Seligson, D., and Hirahara, K. (1957). The measurement o\$ ammonia in whole blood erythrocytes and plasma. J. Lab clin. Med., 49, 962-974.

Sinniah, D., Fulton, T. T., and McCullough, H. The effect of exercise on the venous blood ammonium concentration in man. J. clin. Path., 23, 715-719.

Stahl, J. (1963). Studies of the blood ammonia in liver disease? Ann. inter. Med., 58, 1-24.

Stanojević, L. (1931). La question de l'ammoniaque du sang Bull. Soc. Chim. biol. (Paris), 13, 579-587.

Zieve, L. (1966). Pathogenesis of hepatic coma. Arch. intern. Med 118, 211-223. 